\title{
MODEL PEMBELAJARAN SCRAMBLE UNTUK PENGAJARAN PENDIDIKAN KEWARGANEGARAAN TENTANG MENGHARGAI KEPUTUSAN BERSAMA
}

\author{
Sodikun ${ }^{1)}$ \\ 1) Sekolah Dasar Negeri 1 Jambu Jepara \\ Jl. Jepara - Bangsri KM 13, Jambu Timur, Kecamatan Mlonggo, Jepara, Jawa Tengah 59452 \\ Email: sodikun72@gmail.com
}

\begin{abstract}
ABSTRAK
Berdasarkan pengamatan yang dilakukan bahwa pada proses pembelajaran Pendidikan Kewarganegaraan (PKn), siswa dituntut untuk mencatat materi, mengerjakan LKS, atau mengerjakan soal dari guru. Kegiatan-kegiatan tersebut belum membuat siswa dapat berpikir kritis dan kreatif sesuai dengan tujuan pada pembelajaran PKn. Padahal mata pelajaran PKn membutuhkan pemahaman materi dengan baik karena luasnya kompetensi yang dipelajari oleh siswa. Maka, siswa perlu diberikan kesempatan untuk menggunakan model pembelajaran yang lain pada proses pembelajaran PKn. Penelitian ini bertujuan untuk meningkatkan hasil belajar PKn (Pendidikan Kewarganegaraan) dengan menggunakan model pembelajaran scramble untuk siswa kelas V Sekolah Dasar Negeri 3 Jambu Kecamatan Mlonggo Kabupaten Jepara. Desain penelitian ini menggunakan penelitian tindakan kelas. Penelitian ini dilakukan dalam dua siklus. Berdasarkan hasil tes dalam pelaksanaan pembelajaran dengan model pembelajaran scramble, pada siklus pertama belajar menghargai keputusan bersama belum mencapai hasil yang diharapkan sehingga dapat ditingkatkan pada siklus kedua. Data uji dapat diketahui bahwa siswa yang mencapai nilai $\geq 75$ sebesar $71,43 \%$ pada siklus pertama dan meningkat menjadi $85,71 \%$ pada siklus kedua. Peningkatan hasil belajar tersebut terjadi setelah adanya perbaikan tindakan pada siklus kedua yaitu guru membagi kelompok menjadi lebih jelas, anggota kelompok diperkecil jumlahnya, dan pemberian reward kepada siswa yang tenang. Tindakan diberhentikan pada siklus kedua karena telah mencapai kriteria keberhasilan.
\end{abstract}

Kata kunci: hasil belajar, pendidikan kewarganegaraan, model pembelajaran scramble.

PENDAHULUAN

\section{Latar Belakang}

Berdasarkan Standar Isi Kurikulum Tingkat Satuan Pendidikan (KTSP), mata pelajaran utama dalam sekolah dibagi menjadi 8 mata pelajaran. Mata pelajaran utama tersebut yaitu Pendidikan Agama, Pendidikan Kewarganegaraan (PKn), Bahasa Indonesia, Matematika, Ilmu Pengetahuan Alam (IPA), Ilmu Pengetahuan Sosial, Seni Budaya dan Keterampilan, serta Pendidikan Jasmani, Olahraga dan Kesehatan.
Alokasi waktu pada setiap mata pelajaran dapat dilihat pada tabel berikut:

Tabel 1. Alokasi Waktu Mata Pelajaran di SD/MI

\begin{tabular}{clc}
\hline No & \multicolumn{1}{c}{ Mata Pelajaran } & $\begin{array}{c}\text { Alokasi } \\
\text { Waktu }\end{array}$ \\
\hline 1 & Pendidikan Agama & 3 \\
2 & $\begin{array}{l}\text { Pendidikan Kewarganegaraan } \\
\text { (PKn) }\end{array}$ & 2 \\
3 & Bahasa Indonesia & 5 \\
4 & Matematika & 5 \\
5 & Ilmu Pengetahuan Alam (IPA) & 4 \\
\hline 6 & Ilmu Pengetahuan Sosial (IPS) & 3 \\
7 & Seni Budaya dan Keterampilan & 4 \\
8 & Pendidikan Jasmani, Olahraga, & 4 \\
& dan Kesehatan & \\
\hline
\end{tabular}


Berdasarkan data di atas, maka dapat dilihat bahwa mata pelajaran yang memiliki durasi 2 jam pelajaran dalam seminggu yaitu PKn. Mata pelajaran PKn mempunyai waktu yang paling pendek daripada mata pelajaran yang lain. PKn merupakan mata pelajaran yang membahas tentang pengembangan kemampuan peserta didik agar dapat tumbuh menjadi warga negara yang baik (good citizen). Salah satu aspek yang dibahas dalam Pendidikan Kewarganegaraan yaitu tentang cara berpikir kritis dan kreatif. Hal tersebut didukung dengan pernyataan yang disampaikan oleh Badan Standar Nasional Pendidikan (BSNP) bahwa salah satu tujuan mata pelajaran $\mathrm{PKn}$ yaitu memberikan kompetensi-kompetensi kepada siswa agar mampu berpikir secara kritis, rasional, dan kreatif dalam menanggapi isu kewarganegaraan. Siswa diberi kesempatan untuk berpikir dengan baik dalam menyatakan pendapatnya terhadap masalah kewarganegaraan.

Menurut pengamatan yang dilakukan di kelas V Sekolah Dasar Negeri 3 Jambu Kecamatan Mlonggo Kabupaten Jepara menunjukkan bahwa pada proses pembelajaran PKn, siswa dituntut untuk mencatat materi, mengerjakan LKS, atau mengerjakan soal dari guru. Kegiatan-kegiatan tersebut belum membuat siswa dapat berpikir kritis dan kreatif sesuai dengan tujuan pada pembelajaran PKn. Padahal mata pelajaran PKn membutuhkan pemahaman materi dengan baik karena luasnya kompetensi yang dipelajari oleh siswa. Maka, siswa perlu diberikan kesempatan untuk menggunakan model pembelajaran yang lain pada proses pembelajaran PKn.

Selain hasil pengamatan, proses wawancara bersama guru juga dilakukan untuk mencari kendala yang dihadapi guru dalam proses pembelajaran Pendidikan Kewarganegaraan di kelas. Wawancara yang dilakukan memperoleh hasil sebagai berikut:

Pertama, waktu yang terbatas dan hanya terjadwal $2 \times 35$ menit dalam satu pekan pembelajaran, guru tidak langsung memberikan materi kepada siswa. Ketika pembelajaran dimulai, guru menyuruh siswa untuk tenang ketika proses pembelajaran. Waktu yang digunakan untuk pengkondisian siswa terlalu lamapadahal pembelajaran hanya berlangsung 2 x 35 menit.

Kedua, guru kelas V sudah memiliki pengalaman yang sangat lama dalam mengajar di Sekolah Dasar. Namun kurang mengikuti perkembangan zaman yang sudah maju dengan teknologi dan informasi. Guru lebih senang memberikan materi pembelajaran terkait mata pelajaran yang berkaitan dengan Ujian Nasional. Sehingga mata pelajaran selain yang terdaftar dalam Ujian Nasional tidak mendapat perhatian dengan baik.

Ketiga, siswa yang memiliki latar belakang beragam membuat guru harus memiliki cara agar sikap antar siswa terjaga dengan baik. Sebagian siswa kelas V Sekolah Dasar Negeri 3 Jambu Kecamatan Mlonggo Kabupaten Jepara berasal dari siswa kuang mampu, siswa yang mempunyai orang tua berbeda pemahaman tentang pendidikan, serta siswa yang tidak naik kelas. Kejadian 
tersebut menimbulkan sikap yang kurang baik dalam diri siswa. Sebagai contoh yaitu sering terjadi perkelahian kecil antar siswa walaupun tidak berlangsung lama.

Keempat, hasil belajar siswa kelas V Sekolah Dasar Negeri 3 Jambu Kecamatan Mlonggo Kabupaten Jepara pada mata pelajaran PKn rendah. Hal tersebut disebabkan oleh beberapa faktor. Salah satunya yakni guru yang belum menerapkan model pembelajaran lain selain model satu arah.

\section{Tujuan Penelitian}

Tujuan yang hendak dicapai agar guru-guru dapat mengerti dan memahami tentang Kriteria Ketuntasan Minimal ( KKM ) dan dapat meningkatkan kemampuan guru-guru Sekolah Dasar Negeri 2 Jambu UPT Dinas Dikpora Kecamatan Mlonggo dalam menetapkan Kriteria Ketuntasan Minimal (KKM).

\section{Manfaat Penelitian}

Sedangkan manfaat penelitian adalah dapat memberikan pengalaman belajar bagi guru, karena guru diberikan materi dan latihan menetapkan Kriteria Ketuntasan Minimal ( KKM ) sesuai dengan mata pelajarannya. Guru-guru Sekolah Dasar Negeri 2 Jambu UPT Dinas Dikpora Kecamatan Mlonggo memiliki kemampuan dalam menetapkan Kriteria Ketuntasan Minimal sehingga proses belajar mengajar lebih baik.

\section{TINJAUAN PUSTAKA}

Ilmu pengetahuan semakin berkembang seiring bergantinya zaman. Manusia senantiasa mengasah kemampuannya sesuai bidang yang ditekuni. Kegiatan manusia dalam memenuhi kebutuhan ilmu pengetahuan tidak lepas dari aktivitas belajar. Belajar dapat dilaksanakan di mana saja dan kapan saja.

Aunurrahman (2013: 35) menjelaskan bahwa belajar adalah suatu proses yang dilakukan individu untuk memperoleh suatu perubahan tingkah laku yang baru secara keseluruhan, sebagai hasil pengalaman individu itu sendiri di dalam interaksi dengan lingkungannya. Pernyataan tersebut didukung oleh Purwanto (2009: 3839) yang menyatakan bahwa belajar merupakan proses dalam diri individu yang berinteraksi dengan lingkungan untuk mendapatkan perubahan dalam perilakunya. Syah (2006: 68) menyatakan bahwa belajar dapat dipahami sebagai tahapan perubahan seluruh tingkah laku individu yang relatif menetap sebagai hasil pengalaman dan interaksi dengan lingkungan yang melibatkan proses kognitif. Belajar dapat dinyatakan sebagai kemampuan berpikir seseorang dalam memahami pengalaman yang ada di lingkungan sekitar serta hubungan antar masyarakat.

Atkinson (1983: 283) juga menyatakan bahwa belajar merupakan dasar untuk memahami perilaku. Pokok utama dalam belajar adalah memahami perilaku sebelum menerapkannya dalam lingkungan. Belajar tidak hanya perubahan yang dapat dilihat pada aspek sikap. Majid (2014: 15) menyatakan bahwa belajar pada hakikatnya merupakan proses perubahan di dalam kepribadian yang berupa kecakapan, 
sikap, dan kepandaian. Dikatakan belajar apabila memenuhi aspek kognitif (pengetahuan), afektif (sikap), dan psikomotor (gerak).

Berdasarkan

beberapa

pengertian belajar yang dikemukakan oleh para ahli, maka dapat disimpulkan bahwa belajar merupakan perubahan yang terjadi pada tiga aspek yaitu kognitif, afektif, dan psikomotor melalui beberapa proses mengenal lingkungan sekitar serta pengalaman yang didapat oleh seseorang.

Prastowo $(2015: 162)$ indikator
hasil belajar adalah tujuan
pembelajaran yang diharapkan dapat
dimiliki oleh siswa setelah mereka
melakukan proses pembelajaran
tertentu. Dengan demikian,
indikator hasil belajar merupakan kemampuan siswa yang dapat diobservasi (observable). Artinya apa hasil yang diperoleh siswa setelah mereka mengikuti proses pembelajaran. Menurut abdul Majid, kemampuan siswa yang dapat diobservasi yakni mencangkup ranah atau dimensi pengetahuan (kognitif), keterampilan (psikomotorik), dan sikap (afektif). Ranah kognititf meliputi pemahaman dan pengembangan keterampilan intelektual, dengan tingkatan: ingatan, pemahaman, penerapan/aplikasi, analisis, evaluasi, dan kreasi. Indikator kognitif dapat dipilah menjadi indikator produk dan proses. Indikator hasil belajar menjadi operasionalisasi dari kompetesi dasar. Cara operasionalisasi ini menggunakan kata kerja operasional yang dapat diukur dan diobservasi oleh guru. Berdasarkan pemaparan tentang hasil belajar, maka definisi hasil belajar PKn dapat dinyatakan sebagai perubahan tingkah laku siswa secara keseluruhan mulai dari aspek kognitif, aspek afektif, dan aspek psikomotor. Penelitian tindakan kelas yang dilaksanakan hanya mengukur hasil belajar PKn pada aspek kognitif saja. Hasil penelitian diperoleh dari soal tes yang telah dirancang oleh peneliti bersama guru kelas V sesuai dengan materi yang dipelajari siswa yakni materi keputusan bersama dan menggunakan model pembelajaran scramble.

Trianto (2010:51) menjelaskan bahwa model pembelajaran adalah suatu perencanaan atau suatu pola yang digunakan sebagai pedoman dalam perencanaan pembelajaran di kelas atau pembelajaran dalam tutorial. Model pembelajaran disusun berdasarkan dengan pendekatan yang digunakan serta sesuai dengan tujuan pembelajaran yang ingin dicapai. Hal tersebut sesuai dengan pendapat Arends (Trianto, 2010: 54) menjelaskan bahwa model pembelajaran mengacu pada pendekatan pembelajaran yang akan digunakan, termasuk di dalamnya tujuan-tujuan pengajaran, tahap-tahap dalam kegiatan pembelajaran, lingkungan pembelajaran, dan pengelolaan kelas.

Salah satu model pembelajaran yang diharapkan dapat meningkatkan prestasi siswa adalah model pembelajaran scramble yaitu model pembelajaran menggunakan kartu soal dan kartu jawaban secara bersamaan. Siswa diharapkan untuk menyusun jawaban acak yang telah disiapkan kemudian mencocokkan dengan kartu soal yang ada dengan benar. Model pembelajaran scramble dapat dilaksanakan dengan berbagai 
metode pembelajaran. Salah satu metode yang dapat disajikan dengan menggunakan model pembelajaran scramble yakni metode permainan sehingga tidak membuat siswa jenuh dalam proses belajar mengajar.

Pembelajaran PKn dengan menggunakan model pembelajaran scramble diharapkan mampu meningkatkan pemahaman siswa tentang suatu materi dan dapat meningkatkan hasil belajar siswa. Hasil belajar merupakan hasil dari pencapaian usaha atau proses belajar yang dilakukan siswa. Hasil belajar yang baik adalah hal yang sangat didampakan siswa, guru, dan orangtua siswa. bagan kerangka pikir disampaikan pada gambar 1 sebagai berikut:

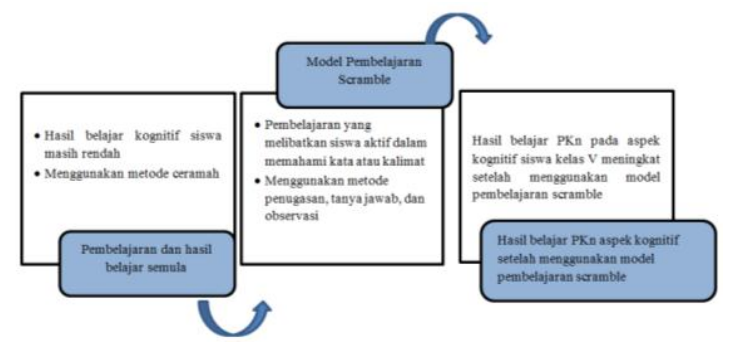

Gambar 1. Bagan Kerangka Berpikir

Berdasarkan kajian pustaka dan kerangka berpikir yang telah diuraikan di atas, dapat dirumuskan hipotesis tindakan bahwa penggunaan model pembelajaran scramble dapat meningkatkan hasil belajar siswa kelas V Sekolah Dasar Negeri 3 Jambu Kecamatan Mlonggo Kabupaten Jepara dalam mata pelajaran PKn.

\section{METODE PENELITIAN}

Jenis penelitian yang digunakan dalam penelitian ini yakni Penelitian Tindakan Kelas (PTK). Arikunto (2015: 1) menjelaskan bahwa penelitian tindakan kelas adalah penelitian yang memaparkan terjadinya sebab-akibat dari perlakuan, sekaligus memaparkan apa saja yang terjadi ketika perlakuan diberikan, dan memaparkan seluruh proses sejak awal pemberian perlakuan sampai dengan dampak dari perlakuan tersebut.

Dalam penelitian ini, peneliti menemukan permasalahan pada pembelajaran PKn kelas V Sekolah Dasar Negeri 3 Jambu Kecamatan Mlonggo Kabupaten Jepara yaitu rendahnya hasil belajar siswa pada mata pelajaran PKn. Masalah dalam proses pembelajaran dapat terkait dengan guru, siswa, sarana prasarana, atau model pembelajaran yang digunakan dalam proses pembelajaran. Menanggapi hal tersebut, peneliti bermaksud mengatasi permasalahan dengan cara melakukan perbaikan proses pembelajaran melalui penelitian tindakan kelas dengan menerapkan model pembelajaran scramble dalam pembelajaran PKn pada siswa kelas V Sekolah Dasar Negeri 3 Jambu Kecamatan Mlonggo Kabupaten Jepara.

Subjek penelitian ini adalah siswa kelas V Sekolah Dasar Negeri 3 Jambu Kecamatan Mlonggo Kabupaten Jepara tahun pelajaran 2016/2017. Jumlah siswa yaitu 35 siswa yang terdiri dari 15 siswa perempuan dan 20 siswa laki-laki. Adapun topik yang dibahas adalah "menghargai keputusan bersama".

\section{Desain Penelitian}

\section{Rancangan Penelitian}

$\begin{array}{ccc}\text { Berdasarkan jenis } & \text { penelitian } \\ \text { yang dipilih, yaitu penelitian }\end{array}$ 
tindakan kelas maka, dalam penelitian ini peneliti menggunakan model penelitian tindakan dari Kemmis dan Taggart yang berbentuk spiral, model penelitian ini saling terkait dari siklus satu ke siklus berikutnya. Berdasarkan Arikunto (2006: 98) menyebutkan bahwa secara utuh, tindakan yang diterapkan dalam penelitian tindakan kelas yakni terdapat 4 tahapan yaitu sebagai berikut: a) Tahap 1: Menyusun rancangan tindakan dan dikenal dengan perencanaan. Tahap 1 menjelaskan tentang apa, mengapa, kapan, di mana, oleh siapa, dan bagaimana tindakan tersebut dilakukan. b) Tahap 2: Pelaksanaan tindakan. Kegiatan pada tahap 2 yaitu implementasi atau penerapan isi rancangan di dalam kancah, yaitu mengenakan tindakan di kelas. c) Tahap 3: Pengamatan. Kegiatan pada tahap 3 yaitu pelaksanaan pengamatan oleh pengamat. Pengamatan dan tindakan diusahakan terjadi pada waktu yang sama. d) Tahap 4: Refleksi, atau pantulan. Kegiatan pada tahap 4 yaitu kegiatan untuk mengemukakan kembali apa yang sudah terjadi. Refleksi biasanya digunakan setelah guru pelaksana melakukan tindakan.

\section{Instrumen Penelitian}

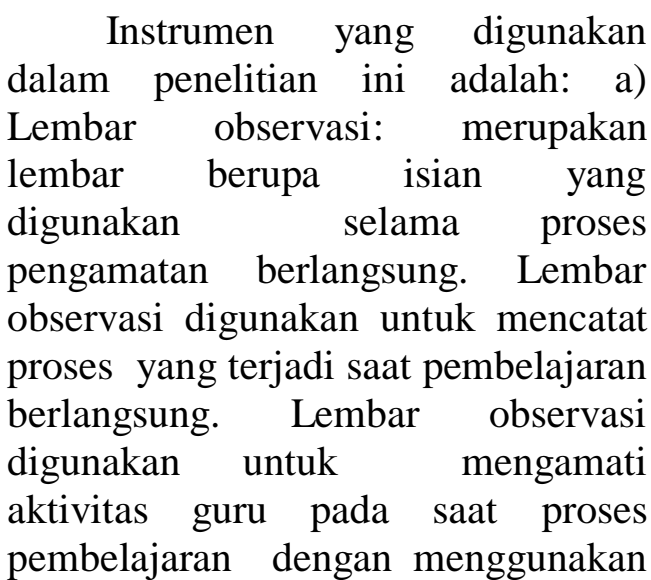

model pembelajaran scramble berlangsung, juga untuk mengetahui pencapaian hasil belajar siswa pada aspek kognitif. b) Soal tes: Purwanto (2006: 33) menyatakan bahwa tes hasil belajar atau achievement test ialah tes yang dipergunakan untuk menilai hasil-hasil pelajaran yang telah diberikan oleh guru kepada murid-muridnya, atau oleh dosen kepada mahasiswa, dalam jangka waktu tertentu. Tes dalam penelitian ini digunakan untuk mengukur tes hasil belajar mata pelajaran PKn. Tes yang digunakan yakni pilihan ganda berjumlah 20 butir soal dengan soal pilihan ganda empat alternatif jawaban yaitu a, b, c, dan d.

\section{Teknik Analisis Data}

Teknik analisis data yang digunakan dalam penelitian ini adalah menggunakan deskriptif kualitatif dan kuantitatif. Data kualitatif didapatkan dari lembar observasi aktivitas guru dalam pembelajaran dengan menggunakan model pembelajaran scramble. Data kualitatif merupakan data yang berupa informasi dalam bentuk kalimat. Data ini bertujuan untuk menggambarkan suatu proses dalam kegiatan pembelajaran. Data kualitatif pada penelitian ini diperoleh dari hasil pengamatan yang dianalisis deskriptif, sehingga diperoleh data mengenai aktivitas pembelajaran PKn yang menggunakan model pembelajaran scramble.

Hasil tes dianalisis dengan cara menghitung dari nilai rata-rata pra siklus kemudian menghitung rata-rata nilai dari akhir setiap siklus. Nilai rata-rata yang diperoleh dari setiap akhir siklus dibandingkan dengan nilai rata-rata pra siklus atau sebelum diberi tindakan. Rumus 
yang digunakan untuk mencari ratarata nilai (Sudijono, 2006: 81) sebagai berikut:

$\mathrm{X}=\frac{\Sigma X}{N}$

Keterangan:

$\mathrm{X}$ : Mean yang dicari

$\sum \mathrm{X}$ : Jumlah skor siswa

$\mathrm{N}$ : Banyaknya siswa

Sedangkan rumus untuk menghitung presentase siswa yang lulus adalah sebagai berikut:

$\mathrm{P}=\frac{F}{N} \times 100 \%$

Keterangan:

$\mathrm{P} \quad$ : angka presentase

F : presentase yang sedang dicari presentasenya (jumlah siswa yang mencapai nilai $\geq \mathrm{KKM}$ [Kriteria Ketuntasan Minimal])

$\mathrm{N}$ : jumlah frekuensi atau banyaknya individu dalam subjek penelitian (jumlah siswa kelas V Sekolah Dasar Negeri 3 Jambu Kecamatan Mlonggo Kabupaten Jepara).

\section{Kriteria Keberhasilan Tindakan}

Kriteria Ketuntasan Minimal (KKM) yang diterapkan pada Sekolah Dasar Negeri 3 Jambu Kecamatan Mlonggo Kabupaten Jepara adalah 75. Siswa dikatakan tuntas dalam pembelajaran apabila mencapai nilai $\geq 75$. Penelitian tindakan kelas ini dikatakan berhasil apabila memenuhi indikator keberhasilan pembelajaran yang ditetapkan. Kriteria dan indikator keberhasilan pembelajaran bahwa tingkat keberhasilan peserta didik dalam menyelesaikan serangkaian tes sesuai dengan standar kompetensi dan kompetensi dasar yang ideal yakni 75\%. Maka dari uraian tersebut, pembelajaran dengan menggunakan model pembelajaran scramble dikatakan dapat meningkatkan hasil belajar PKn pada siswa kelas V Sekolah Dasar Negeri 3 Jambu Kecamatan Mlonggo Kabupaten Jepara apabila minimal $75 \%$ dari jumlah siswa mencapai KKM yaitu $\geq 75$.

\section{HASIL DAN PEMBAHASAN}

\section{Deskripsi Data Kondisi Awal}

Berdasarkan hasil observasi guru kelas sebelum dilakukan tindakan, nilai hasil belajar PKn Pra Siklus dapat dilihat pada tabel 2:

Tabel 2. Hasil Belajar Pra Siklus

Sekolah Dasar Negeri 3 Jambu

\begin{tabular}{|c|c|c|c|}
\hline No & Nilai & $\begin{array}{c}\text { Jumlah } \\
\text { Siswa } \\
\end{array}$ & Kriteria \\
\hline 1 & 80 & 4 & Tuntas \\
\hline 2 & 76 & 6 & Tuntas \\
\hline 3 & 73 & 2 & Belum Tuntas \\
\hline 4 & 70 & 2 & Belum Tuntas \\
\hline 5 & 63 & 4 & Belum Tuntas \\
\hline 6 & 60 & 2 & Belum Tuntas \\
\hline 7 & 56 & 2 & Belum Tuntas \\
\hline 8 & 50 & 2 & Belum Tuntas \\
\hline 9 & 46 & 2 & Belum Tuntas \\
\hline 10 & 43 & 4 & Belum Tuntas \\
\hline 11 & 40 & 2 & Belum Tuntas \\
\hline 12 & 23 & 2 & Belum Tuntas \\
\hline Jumlah & 2097 & 35 & Belum Tuntas \\
\hline \multicolumn{2}{|c|}{ Rata-Rata } & 59,91 & \\
\hline
\end{tabular}

Data tabel 2 menunjukkan bahwa siswa yang tuntas KKM 75 dalam tes pra siklus hanya mencapai 10 siswa atau $28,57 \%$ sedangkan siswa yang masih di bawah KKM sebanyak 25 siswa atau 71,43\%. Nilai rata-rata kelas pada pra siklus sebesar 
59,91. Dengan nilai terendah adalah 23 dan nilai tertinggi adalah 80 .

Berdasarkan data di atas, dapat dilihat hasil belajar kognitif PKn pada pra siklus masih rendah. Oleh karena itu, diperlukan adanya suatu tindakan untuk meningkatkan hasil belajar kognitif PKn pada siswa kelas $\mathrm{V}$ semester 2 tahun pelajaran 2016/2017 Sekolah Dasar Negeri 3 Jambu.

\section{Deskripsi Hasil Penelitian}

\section{Deskripsi Hasil Siklus I}

Pada akhir siklus, guru sudah menunjukkan adanya peningkatan dalam menerapkan aspek pada model pembelajaran scramble dengan baik. Guru mulai memahami berbagai aspek dalam menerapkan model pembelajaran scramble. Hal tersebut membuat para siswa juga mulai memahami dan menerapkan model pembelajaran scramble dengan baik hasilnya dapat dilihat pada tabel 3 .

Tabel 3. Nilai Hasil Belajar Siklus I

\begin{tabular}{cccc}
\hline No & \multirow{2}{*}{ Kriteria } & \multicolumn{2}{c}{ Siklus I } \\
\cline { 3 - 4 } & Ketuntasan & Jumlah & Persen \\
\hline 1 & Tuntas & 25 & $71,43 \%$ \\
2 & Belum tuntas & 10 & $28,57 \%$ \\
\hline & Rata-rata & & $\mathbf{7 5 , 2 9}$ \\
\hline
\end{tabular}

Pada hasil belajar tersebut dapat dilihat siswa yang tuntas sebanyak 25 siswa sebesar 71,43\% dan yang belum tuntas sebanyak 10 siswa atau sebesar $28,57 \%$ dengan rata-rata sebesar 75,29. Berdasarkan data tersebut dapat disimpulkan bahwa hasil belajar PKn siswa kelas V Sekolah Dasar Negeri 3 Jambu sudah meningkat dari hasil belajar yang dilakukan pada pra siklus. Namun hasil belajar pada siklus I masih rendah dan belum mencapai kriteria keberhasilan yakni $75 \%$. Hasil perbandingan belajar pada pra siklus dan siklus I dapat dilihat pada tabel 4.

Tabel 4. Perbandingan Nilai Pra Siklus dan Siklus I

\begin{tabular}{|c|c|c|c|c|}
\hline \multirow[t]{2}{*}{ Kriteria } & \multicolumn{2}{|c|}{ Nilai Pra Siklus } & \multicolumn{2}{|c|}{ Siklus I } \\
\hline & Jumlah & $\begin{array}{c}\text { Persen } \\
(\%)\end{array}$ & Jumlah & $\begin{array}{c}\text { Persen } \\
(\%)\end{array}$ \\
\hline Tuntas & 7 & $20 \%$ & 25 & $71,43 \%$ \\
\hline $\begin{array}{l}\text { Belum } \\
\text { tuntas }\end{array}$ & 28 & $80 \%$ & 10 & $28,57 \%$ \\
\hline Rata-rata & \multicolumn{2}{|c|}{59,89} & \multicolumn{2}{|c|}{75,86} \\
\hline
\end{tabular}

Dari tabel di atas dapat dilihat bahwa terjadi peningkatan dari nilai pra siklus ke siklus I. Siswa yang tuntas pada pra siklus sebanyak 7 siswa atau sebesar $20 \%$ menjadi 28 siswa atau sebesar $80 \%$ pada siklus I. Siswa yang belum tuntas pada pra siklus sebanyak 25 siswa atau sebesar $71,43 \%$ menjadi 10 siswa atau sebesar $28,57 \%$ pada siklus I. sedangkan nilai rata-rata pada pra siklus 59,89 menjadi 75,86 pada siklus I.

Peningkatan hasil belajar pra siklus dan siklus I dapat dilihat juga pada diagram batang berikut ini:

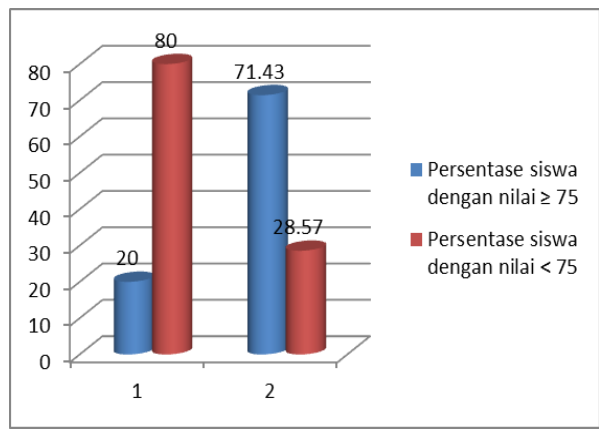

Gambar 2. Diagram Perbandingan Hasil Belajar Pra Siklus dan Siklus I

\section{Deskripsi Hasil Siklus II}

Pada siklus II siswa terlihat lebih tenang dan memahami pembelajaran yang disampaikan 
guru. Siswa dapat mengerjakan tugas yang diberikan oleh gurudengan baik dan tepat. Hal tersebut dikarenakan siswa diberi waktu lebih lama. Hasil siklus II berupa rata-rata nilai evaluasi mengalami peningkatan dari siklus I. Berikut tabel nilai hasil belajar siklus II Sekolah Dasar Negeri 3 Jambu.

Tabel 5. Nilai Hasil Belajar Siklus II

\begin{tabular}{llcc}
\hline No & Kriteria & \multicolumn{2}{c}{ Siklus II } \\
\cline { 3 - 4 } & Ketuntasan & Jumlah & Persen \\
\hline 1 & Tuntas & 30 & $85,71 \%$ \\
2 & Belum tuntas & 5 & $14,29 \%$ \\
\hline & Rata-rata & & $\mathbf{7 5 , 8 6}$ \\
\hline
\end{tabular}

Dari data tersebut dapat dilihat bahwa siswa yang tuntas sebanyak 30 siswa atau sebesar $85,71 \%$. Sedangkan siswa yang belum tuntas sebanyak 5 siswa atau sebesar $14,29 \%$. Rata-rata hasil belajar pada siklus II mencapai 75,86.

Berdasarkan data tabel di atas, dapat disimpulkan bahwa hasil belajar PKn siswa kelas V Sekolah Dasar Negeri 3 Jambu pada siklus II mengalami peningkatan dari nilai rata-rata pra siklus dan siklus I. peningkatan nilai rata-rata kelas $\mathrm{V}$ pada siklus II sudah sesuai dengan kriteria keberhasilan yang ingin dicapai pada penelitian ini. Berikut tabel perbandingan hasil belajar nilai pra sikus, Siklus I, dan Siklus II.

Tabel 6. Perbandingan Hasil Belajar Nilai PraSiklus, Siklus I, dan Siklus II

\begin{tabular}{lcccccc}
\hline \multirow{2}{*}{ Kriteria } & \multicolumn{2}{c}{ Nilai PraSiklus } & \multicolumn{2}{c}{ Nilai Siklus I } & \multicolumn{2}{c}{ Nilai Siklus II } \\
\cline { 2 - 7 } & Jumlah & $\mathbf{\%}$ & Jumlah & $\mathbf{\%}$ & Jumlah & $\%$ \\
\hline Tuntas & 7 & 20 & 25 & 71.43 & 30 & 85,71 \\
Belum tuntas & 28 & 80 & 10 & 28,57 & 5 & 14,29 \\
\hline Rata-Rata & $\mathbf{5 9 , 8 9}$ & $\mathbf{7 5 , 8 6}$ & $\mathbf{8 3 , 0 0}$ \\
\hline
\end{tabular}

$\begin{array}{llr}\text { Data } & \text { tabel di atas } \\ \text { menunjukkan } & \text { bahwa nilai hasil } \\ \text { belajar siswa } & \text { meningkat dari nilai } \\ \text { pra siklus ke } & \text { siklus I dan siklus }\end{array}$

II. Siswa yang tuntas pada nilai pra siklus sebanyak 7 siswa atau sebesar $20 \%$ menjadi 25 siswa atau sebesar $71,43 \%$ pada siklus I dan mencapai 30 siswa atau $85,71 \%$ pada siklus II. Siswa yang belum tuntas pada nilai pra siklus sebanyak 28 siswa atau $80 \%$ menjadi 10 siswa atau sebesar $28,57 \%$ pada siklus I dan mencapai 5 siswa atau 14,29\% pada siklus II. Sedangkan nilai rata-rata pada nilai pra siklus sebesar 59,89 menjadi 75,86 pada siklus I dan mencapai 83,00 pada siklus II. Peningkatan hasil belajar dari pra siklus sampai siklus I dan siklus II dapat dilihat juga pada diagram batang berikut ini:

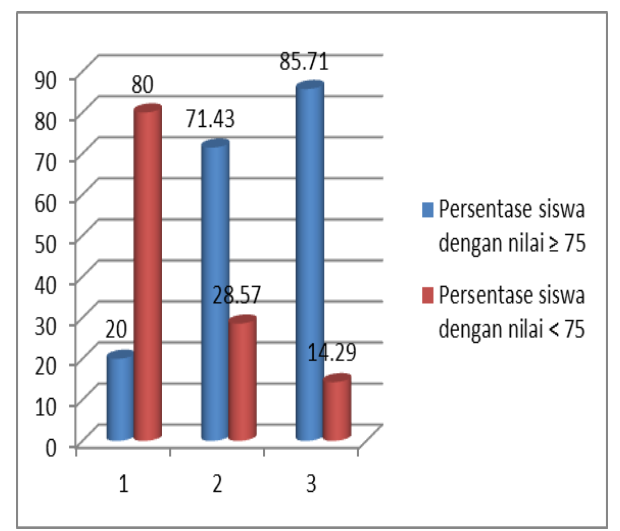

Gambar 3. Diagram Perbandingan

Hasil Belajar Pra Siklus, Siklus I, dan Siklus II

Rangkaian penelitian tindakan kelas dilaksanakan dalam 2 siklus yang masing-masing siklus terdiri dari 2 pertemuan. Nilai rata-rata siswa dan persentase jumlah siswa yang mencapai KKM $(\geq 75)$ meningkat setelah dilaksanakan tindakan pada siklus I dan siklus II.

Nilai rata-rata hasil belajar PKn pada pra siklus sebesar 59,89 dengan jumlah siswa yang memnuhi KKM yakni 2 siswa atau setara dengan 29,41\% dari jumlah total siswa. Setalah dilaksanakan siklus I, 
nilai rata-rata hasil belajar $\mathrm{PKn}$ meningkat menjadi 75,86 dengan jumlah siswa yang memenuhi KKM yakni 25 siswa atau setara dengan $71,43 \%$ dari jumlah total siswa. Siklus II dilaksanakan karena kriteria keberhasilan dari peneliti belum terpenuhi. Nilai rata-rata hasil belajar PKn pada siklus II meningkat kembali menjadi 83,00 dengan jumlah siswa yang memnuhi KKM yakni 15 siswa atau setara dengan 88,24\%. Hal tersebut menunjukkan bahwa pembelajaran PKn yang menggunakan model pembelajaran scramble dapar meningkatkan hasil belajar kognitif siswa pada mata pelajaran PKn siswa kelas V di Sekolah Dasar Negeri 3 Jambu. Pembelajaran PKn dengan menggunakan model pembelajaran scramble menjadikan siswa aktif dalam pembelajaran di kelas maupun diskusi kelompok bersama teman. Hal tersebut sesuai dengan pendapat Asih (2013: 33) model pembelajaran memiliki dampak instruksional dan dampak pengiring pada siswa. Dampak instruksional model pembelajaran scramble yaitu siswa menjadi lebih aktif, berani mengemukakan pendapat dan aktif berdiskusi.

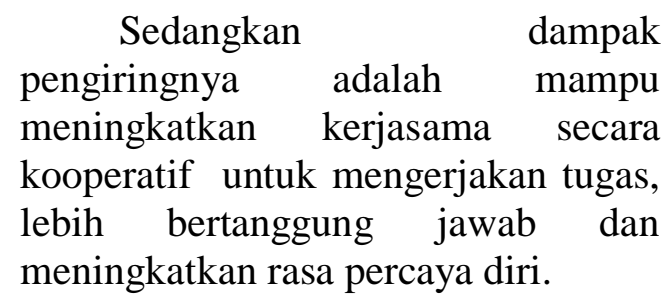

\section{SIMPULAN}

Dari uraian di muka dapat dibuat simpulan bahwa:

1. Langkah-langkah dalam model pembelajaran scramble dapat berjalan dengan baik. Hal tersebut ditunjukkan dengan pelaksanaan langkah-langkah pada model pembelajaran scramble yang telah dilaksanakan secara keseluruhan. Sehingga hasil belajar kognitif siswa kelas $\mathrm{V}$ Sekolah Dasar Negeri 3 Jambu dapat meningkat. Hal tersebut ditunjukkan dengan peningkatan nilai rata-rata kelas pada pelaksanaan pra siklus yakni 59,89 meningkat di siklus I menjadi 75,86 serta meningkat kembali pada siklus II menjadi 83,00 .

2. Peningkatan juga terjadi pada jumlah siswa yang nilainya memenuhi KKM ( $\geq 75)$ yaitu pada pra siklus hanya 5 siswa yang tuntas atau $29,41 \%$ meningkat di siklus I menjadi 12 siswa atau $70,59 \%$ dan meningkat kembali di siklus II menjadi 15 siswa atau $88,24 \%$. Peningkatan hasil belajar kognitif siswa kelas V Sekolah Dasar Negeri 3 Jambu dikarenakan guru menggunakan model pembelajaran scramble sehingga menjadikan siswa mampu mengerjakan soal dengan mudah karena sudah tersedia alternatif jawaban.

\section{DAFTAR PUSTAKA}

Arikunto, S. (2006). Prosedur Penelitian: Suatu Pendekatan Praktik (Edisi Revisi VI). Jakarta: Rineka Cipta.

Atkinson, R. L. etc. (1983). Pengantar Psikologi. Jakarta: Erlangga.

Aunurrahman. 2013. Belajar dan Pembelajaran. Bandung: Alfabeta 
BSNP. 2006. Standar Isi untuk Satuan Pendidikan Dasar dan Menengah. Jakarta: BSNP.

Majid, A. 2014. Pembelajaran Tematik Terpadu. Bandung: Remaja roSekolah Dasarakarya.

Prastowo, A. 2015. Menyusun Rencana Pelaksanaan Pembelajaran (RPP) Tematik Terpadu: Implementasi Kurikulum 2013 untuk Sekolah Dasar/MI. Jakarta: Prenadamedia Group.

Purwanto, N. 2006. Prinsip-Prinsip dan Teknik Evaluasi Pengajaran. Bandung: Remaja RoSekolah Dasarakarya.

Purwanto. 2009. Evaluasi Hasil Belajar. Yogyakarta: Pustaka Belajar.

Sudijono, A. 2006. Pengantar Statistik Pendidikan. Jakarta: Raja Grafindo Persada.

Syah, M. 2006. Psikologi Belajar. Jakarta: Raja Grafindo Persada

Trianto. 2010. Model Pembelajaran Terpadu: Konsep, Strategi, dan Implementasinya dalam Kurikulum Tingkat Satuan Pendidikan (KTSP). Jakarta: Bumi Aksara.

UUD 45 dan perubahannya: susunan kabinet RI lengkap (1945-2009) resufle kabinet Indonesia bersatu. (2004). Jakarta: Kawan Pustaka. 
